\title{
El nacimiento de un municipio industrial en la Bahía de Santander: Astillero (Cantabria) entre los siglos XIX y XX
}

The birth of an industrial municipality on Santander bay: Astillero (Cantabria) from the nineteenth to twentieth century

\author{
Gerardo J. Cueto Alonso \\ gerardo.cueto@unican.es \\ Departamento de Geografía, Urbanismo y Ordenación del Territorio \\ Universidad de Cantabria (España)
}

\section{Resumen}

A mediados del siglo XIX, Astillero, un pequeño y tranquilo pueblo al Suroeste de la Bahía de Santander, era un lugar de veraneo frecuentado por la burguesía santanderina e incluso por algunas familias madrileñas. Las casas de baños, las quintas de recreo y los establecimientos hoteleros formaban parte de su paisaje. Sin embargo, en poco tiempo todo cambió; el desarrollo minero e industrial fue paulatinamente haciendo desaparecer este idílico paisaje, que fue sustituido por chimeneas y almacenes industriales, cargaderos de mineral y petróleo, diques para la construcción de barcos... En definitiva, la pujanza de estas nuevas actividades económicas desterró los usos turísticos como ocurría en esos años en otros núcleos del Norte de España.

Palabras clave: minería; industria; turismo; Cantabria; siglos XIX y XX.

\footnotetext{
Abstract

In the mid nineteenth century, Astillero, a small and tranquil town on the southwest of Santander Bay, was a summer resort frequented by the Santander bourgeoisie and even by some families from Madrid. The bathing houses, recreational villas and hotel establishments formed part of the 
landscape. Nevertheless, in a short time everything changed; the development of mining and industry was gradually making this idyllic landscape disappear, and it was replaced by chimneys and industrial warehouses, loading docks for minerals and petroleum, docks for the construction of ships, etc. Definitively, the la boom in these new economic activities banished the touristic uses as it happened in other nuclei of the North of Spain during this period.

Key words: mining; industry; tourism; Cantabria; 19th and 20th century.

\section{Introducción}

Astillero, un pequeño y tranquilo pueblo situado al Suroeste de la Bahía de Santander, vivió una notable transformación social, económica y territorial durante la última década del siglo XIX (Figura 1). Todo comenzó cuando "un día palpóse las entrañas a mayor hondura que palparlas solía la reja del arado y notó que sus entrañas eran de hierro, y despedazándoselas entró en la era de su grandeza" (Aguirre, 1910, p. 1). La extracción de mineral de hierro en las montañas cercanas de Cabarga representó el final de una época marcada por las actividades tradicionales como la pesca, la agricultura o un balbuceante turismo y marcó el inicio de otra, en la que la minería y la industria ligada a ella se convirtieron en las principales actividades económicas de los astillerenses. El crecimiento demográfico del municipio discurrió paralelo a la irrupción de estas nuevas actividades económicas. Mientras a mediados del siglo XIX Madoz indicaba que en Astillero tan sólo vivían 331 almas y en Guarnizo 183, en 1897 cuando se estaba produciendo el despegue de la actividad minera, el municipio contaba con una población de hecho de 2880 habitantes, y en 1910 en pleno auge minero ascendía a 5782 habitantes.

\section{Figura 1. Plan de la Bahía de Santander (1908)}

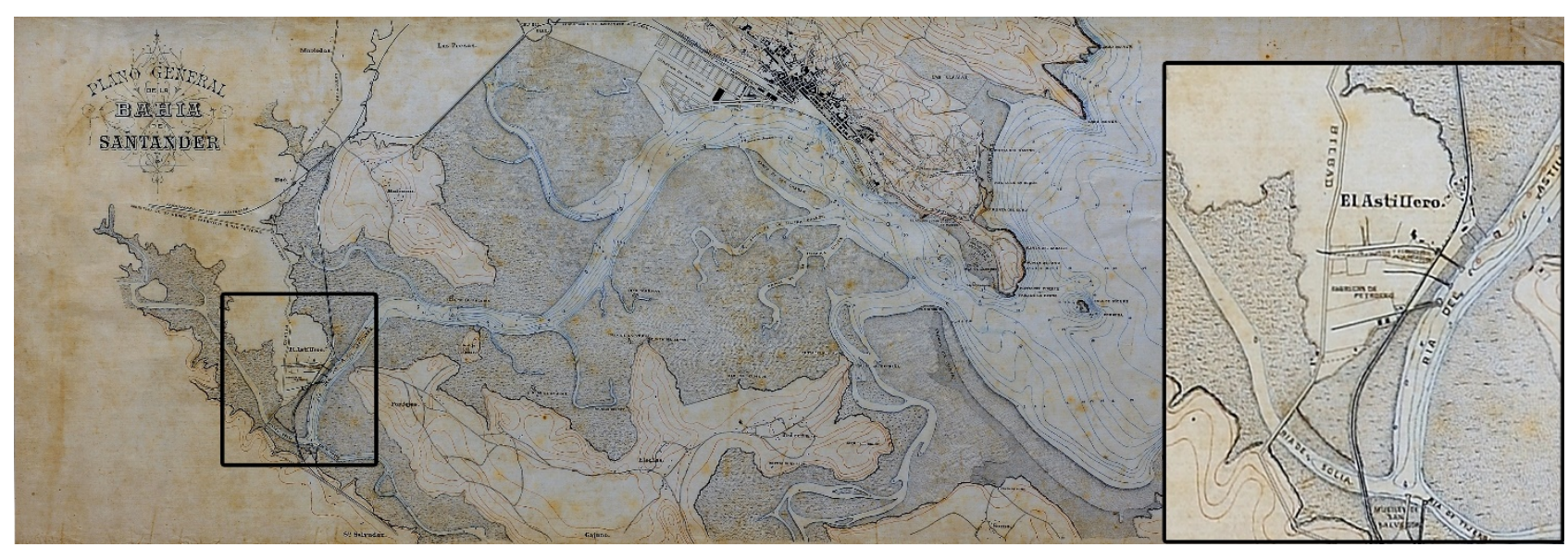

Fuente: elaboración propia a partir del Archivo de la Autoridad

Portuaria de Santander (AAPS) (1908), Plano T24/5 
Para conocer la transformación de Astillero durante el periodo considerado se ha recurrido a las fuentes habitualmente empleadas en cualquier estudio de Geografía Histórica: revisión de la bibliografía tanto actual como de la época, vaciado de la documentación depositada en archivos locales y nacionales y la búsqueda hemerográfica de información relevante. Habida cuenta de que el proceso que vivió Astillero no fue desde luego infrecuente en la costa cantábrica se procedió a la exploración de la bibliografía sobre el veraneo en otras localidades donde el desarrollo industrial confinó o apartó los usos de ocio, como Portugalete (Beascoechea Gangoiti, 2002), Bilbao (Cava Mesa, 2009; Macías, 2009), Gijón, Avilés (De la Madrid, 2011; Roza Candás, 1995) y el casco urbano de la ciudad de Santander (Gil de Arriba, 1992). La documentación archivística más interesante, por cuanto aparte de las fuentes escritas también pudo aportar cartografía, se localizó en dos archivos: el General de la Administración y el de la Autoridad Portuaria de Santander, por cuanto el municipal de Astillero tan sólo disponía de alguna fotografía. El desarrollo industrial y minero de Astillero era bien conocido en el momento de inicio de la investigación (Cueto Alonso, 2006; Ortega Valcárcel, 1986; Arce Pinedo \& Miguel González, 2002; Mercapide Compains, 1977; Fernández Vega \& Sánchez Landeras, 2013) pero, por el contrario, su etapa anterior, es decir la turística, apenas ocupaba breves líneas en obras de carácter general (Gil de Arriba, 1992; Sazatornil Ruiz, 2009) o en historias locales (Arce Pinedo y Miguel González, 2002). Por tanto, para descubrir las características de este periodo se tuvo que recurrir a la consulta de obras publicadas en la época (Adrau y Cornés, 1877; Asúa \& Campos, 1925; Madoz, 1984) y especialmente a la prensa. Desgraciadamente los periódicos cántabros de información general del siglo XIX y principios del XX no se encuentran digitalizados, por lo que se tuvo que realizar una consulta selectiva en papel en la Hemeroteca Municipal de Santander. Sin embargo, la abundante prensa madrileña accesible en las hemerotecas digitales de la Biblioteca Nacional y el Ministerio de Cultura permitió mediante sencillas búsquedas (como "Astillero" y "veraneo") subsanar las lagunas que pudieran existir.

En definitiva, con estos mimbres se ha podido reconstruir el periodo que abarca la segunda mitad del siglo XIX y los primeros lustros del siguiente, cuando Astillero ascendió "de aldea veraniega y burgo labriego-pescador de indígenas anfibios, a la categoría de población fabril y comercial, donde se albergan media docena de miles de almas y donde las tahonas cuecen pan destinado a muchos centenares de obreros" (Aguirre \& Escalante, 1910, p. 1).

\section{La difícil convivencia entre el turismo y las actividades industriales}

La segunda mitad del siglo XIX fue una época de cambios en la economía de la Región Cantábrica. A mediados de siglo las aguas del mar Cantábrico propiciaron el desarrollo del turismo y el ocio siguiendo las teorías higienistas imperantes en ese momento. Simultáneamente otras actividades iniciaban su despegue, como la minería, tanto la energética para abastecer a las fábricas locales 
como la metálica para abastecer de materia prima a las europeas, y la industria, especialmente la siderúrgica, con la difusión de modernos altos hornos que aprovechaban la riqueza ferrífera de la región; para un adecuado crecimiento de estas actividades fue necesario el acondicionamiento de los puertos cantábricos, en cuyo proceso jugó un papel esencial el ferrocarril que los conectaba con el interior peninsular. Precisamente el desarrollo industrial propició el surgimiento de una nueva burguesía que a semejanza de la aristocracia demandaba sus propios espacios de ocio. En definitiva, nos encontrábamos con unas actividades que confluían en determinados puntos de la costa y que eran difícilmente conciliables como el ocio y la industria, la minería o la actividad portuaria. Una tensión que se resolverá favorablemente en la mayor parte de los casos para la industria imponiendo una zonificación de los usos y desterrando los baños de las zonas industriales.

Con anterioridad a que los baños de ola se pusieran de moda, el ocio burgués y aristocrático se circunscribía a las temporadas de descanso que las familias urbanas pudientes realizaban en sus quintas de recreo o casas de campo próximas a las ciudades (Ortega Valcárcel, 1986, p. 413); asimismo, a las playas y establecimientos termales de interior del Norte de España también acudían algunas familias procedentes del centro peninsular que huían del rigor climático estival (Beascoechea Gangoiti, 2001, p. 183).

El mar y sus playas nunca habían sido un entorno atractivo, por cuanto era un medio desconocido y hostil; el único interés de las playas, aparte del portuario, radicaba en la extracción de arenas, rocas y algas (Larrinaga, 2015, p. 69; De la Madrid, 2011, p. 21). Esta aversión hacia el mar se fue moderando a medida que se difundieron las ideas higienistas nacidas en Gran Bretaña en el siglo XVIII y que poco a poco fueron calando en Europa a lo largo del siguiente siglo. El higienismo identificaba el entorno social y ambiental en la génesis y desarrollo de enfermedades, por lo que recomendaba una vida sana fuera de esos lugares perniciosos que eran las ciudades industriales. Las topografías médicas basadas en teorías climatistas difundieron la benignidad de determinadas zonas (Gil de Arriba, 1994, p. 82; Sazatornil Ruiz, 2009, p. 134). La recomendación de los tratamientos hidrológicos como remedio profiláctico y terapéutico llevó al sector acomodado de la sociedad a frecuentar en primer lugar los balnearios de aguas termales y posteriormente las playas para tomar baños de ola (Larrinaga, 2002, p. 166-168). En el último cuarto del siglo XIX este modelo higienista ya se encontraba plenamente asentado en la sociedad; no en vano desde los años cuarenta se venían publicando tratados sobre los beneficios de los baños de mar que se recomendaban para un amplio espectro de enfermedades respiratorias cardiacas o dermatológicas (Gil de Arriba, 1994, p. 84). No obstante, no todas las aguas marinas eran apropiadas, se insistía sobre todo en la bondad de las aguas frías, especialmente para fortalecer las fibras, tonificar y dar fluidez a la articulación sanguínea (Cava Mesa, 2009, p. 369), lo que explica que los arenales del norte de España comenzaran a ser valorados por las propiedades salutíferas de sus aguas (Sazatornil Ruiz, 2007, p. 55; Larrinaga, 2015, p. 69-70). 
Los avances médicos, especialmente en bacteriología e inmunología, postergaron el valor curativo de las aguas, si bien a finales de siglo ya se había producido el cambio de la lógica terapéutica a la del ocio (Gil de Arriba, 1992, p. 36). Los centros balnearios del litoral se habían orientado definitivamente hacia el ocio, lo que explicaba la proliferación de casinos, teatros o hipódromos; en definitiva, de lugares de esparcimiento para la burguesía durante el veraneo.

A mediados del siglo XIX también se asistió a una evolución significativa en dos sectores de destacado peso en la economía del Norte de España: la siderurgia y la minería. Las ferrerías del Cantábrico se iban quedando obsoletas y eran relevadas por los primeros altos hornos al coque que utilizaban la hulla asturiana (posteriormente también la inglesa, sobre todo en Vizcaya) y el mineral de hierro presente en numerosos yacimientos del norte de España, pero especialmente abundantes en Vizcaya. En Asturias estas fundiciones se instalaron próximos a los yacimientos de la cuenca central, mientras en Vizcaya lo hicieron en la margen izquierda de la ría de Bilbao. La mayor demanda de combustible obligó a cambiar los sistemas de explotación de las minas de carbón asturianas, abandonando paulatinamente la conocida como "minería de paisanos" en favor de un sistema más racional. Este mineral no sólo abasteció a la industria de la Cornisa Cantábrica, sino que gracias a las mejoras en las infraestructuras de transporte pudo acceder al mercado nacional (Suárez Antuña, 2006). Por su parte, las crecientes necesidades mineral de hierro con bajo contenido en fósforo que demandaba la industria siderúrgica europea, escaso en el resto del continente pero muy abundante en esta provincia, propició el despegue de la actividad en Vizcaya en los años setenta del siglo XIX (Escudero, 1998). Dos décadas más tarde también se pusieron en explotación a gran escala las minas de la Bahía de Santander de características químicas muy similares a las de Vizcaya (Cueto Alonso, 2006). Para el desarrollo de la minería y la industria era necesario acondicionar los principales puertos del Cantábrico, especialmente una vez que dispusieron de conexión ferroviaria con el interior peninsular. Así, las viejas infraestructuras portuarias quedaron en poco tiempo obsoletas, por lo que fue necesario acometer planes de ampliación de su superficie de almacenaje, aumento de los calados para permitir el acceso de buques de mayor porte o construcción de drops y cargaderos de mineral.

Las necesidades de espacio para las nuevas fábricas y puertos colisionaron en algunos lugares con los intereses turísticos, particularmente los ligados a los baños de ola. Los turistas demandaban un entorno sano y apacible que difícilmente podían ofrecer las fábricas, minas y puertos con su trasiego, humos o contaminación. Igualmente, las playas se ofrecían como un lugar apropiado para establecer las nuevas infraestructuras portuarias. La convivencia entre ambas actividades era prácticamente imposible, por lo que se impuso la segregación espacial de usos, diferenciando claramente las zonas recreativas y de práctica balnearia de las industriales, portuarias o mineras. La mayor parte de los lugares de la costa donde se había producido un incipiente núcleo turístico con zona de baños cedió el paso a la industria, que atrajo los recursos y capitales, por cuanto todavía 
"el veraneo no pasaba de ser un divertimento no siempre justificado" (Ortega Valcárcel, 1986, p. 420). La mentalidad industrializadora resultó la triunfadora, si exceptuamos la ciudad de San Sebastián, donde los usos industriales se desplazaron hacia el puerto de Pasajes (Zurbano Melero, 2003, p. 421) o Comillas, donde una apenas arraigada minería del zinc no fue un obstáculo para el veraneo aristocrático (Gil de Arriba, 1990, p. 114). Ejemplos en el sentido contrario salpican muchos rincones del Cantábrico, en los que casas de baños y balnearios debieron ceder su espacio a instalaciones industriales, cargaderos de mineral, tinglados portuarios y malecones.

El abra de Bilbao ofrecía un buen lugar para el desarrollo del ocio antes del despegue industrial, lo que explica la creación de áreas de baño en núcleos como Portugalete, Algorta, Santurce o Las Arenas de Guecho (Beascoechea Gangoiti, 2002, p. 190). Sin embargo, no todas ellas pudieron resistir el empuje de la industria y un puerto que crecía hacia el exterior; como tampoco sobrevivieron los efímeros establecimientos de baños instalados en Bilbao (Cava Mesa, 2009, p. 372).

Portugalete había alcanzado a mediados del siglo XIX una excelente reputación como villa veraniega para los bilbaínos que se desplazaban diariamente en lanchas, o en tranvía posteriormente, a tomar los baños de mar, y para una colonia fija de veraneantes que disponían de su residencia secundaria o que alquilaban alguna casita durante la temporada estival (Macías, 2009, p. 6). En 1878 se levantó un edificio de balneario que mantuvo su actividad hasta los primeros años del siglo XX. Aunque su playa era escasa concitaba suficientes visitantes que no buscaban el lujo y la ostentación de otras estaciones del Cantábrico, no obstante la ampliación del puerto y la alineación definitiva del muelle redujeron la playa a la mínima expresión (Beascoechea Gangoiti, 2002, pp. 192-193), lo que evidenciaba que la margen izquierda de la ría se iba consolidando como un espacio industrial con numerosos establecimientos fabriles y viviendas obreras que no era compatible con el uso recreativo que había tenido en décadas pasadas.

La construcción del puerto exterior de Bilbao también influyó en la desaparición de otra estación balnearia, en este caso en la margen derecha: Las Arenas de Guecho. Las obras del puerto socavaron la playa local y arruinaron la galería balnearia a finales de siglo (Cava Mesa, 2009, p. 373; Beascoechea Gangoiti, 2002, p. 201). No obstante, sobre la línea de playa se construyó un nuevo paseo urbano y se consolido la edificación, convirtiendo a la localidad en lugar de residencia permanente de la burguesía industrial y comercial vizcaína. En este caso, la industrialización fue un efecto colateral, por cuanto nunca llegaron a convivir ambas actividades en el mismo espacio.

Varios puntos de la costa asturiana como Luanco, Candás, Gijón y Salinas eran del gusto de los veraneantes, fundamentalmente locales, a mediados del siglo XIX. Las primeras playas utilizadas para el baño en Gijón se localizaban en el occidente del cerro de Santa Catalina, como los arenales de Poniente, el Natahoyo, la Gloria y Pando, la más concurrida, y en la zona trasera de la 
iglesia de San Pedro, donde el ayuntamiento había construido una batería de casetas (De la Madrid, 2011, p. 42; Roza Candás, 1995, p. 90). Los baños Ilamaron la atención de la familia real que pasó en Gijón varias semanas del verano de 1858, durante las que Isabel II tomó las aguas en la playa de Pando. La expectativa de que la ciudad fuera elegida como residencia real veraniega explica el proyecto de construcción de dos balnearios en esta playa, que nunca se llevarían a cabo, ya que el futuro deparaba otro uso a ese espacio. La ciudad se postulaba como la salida marítima del carbón de la cuenca central asturiana una vez que se había concluido el Ferrocarril de Langreo con un ramal hacia el viejo puerto, que requería una ampliación que sólo podía hacerse a costa del arenal; curiosamente los baños no desaparecieron definitivamente, sino que las casetas abandonaron la playa y se subieron a los paredones (De la Madrid, 2011, pp. 51-55). Paralelamente al decaimiento del occidente de Santa Catalina como zona de baños fue creciendo el del arenal de San Lorenzo, donde a partir de los setenta se fueron instalando los primeros balnearios de la ciudad, estableciéndose una clara zonificación de usos separados por el cerro "a un lado el Gijón alegre y al otro el que respira por centenares de chimeneas de sus fábricas" (De la Madrid, 2011, p. 63).

Avilés no disponía de una playa en su término municipal, si bien había alguna zona de baño para gente modesta en la propia ría (De la Madrid, 2011, p. 45). En realidad, la "playa de Avilés" se encontraba en el municipio vecino de Castrillón, concretamente en la localidad de Salinas, que había crecido semisalvaje "dejada de la civilización o más bien civilizada para el veraneo por sus primeros exclusivos veraneantes", sobre terrenos propiedad de la Real Compañía Asturiana de Minas (De la Madrid, 2011, p. 82). Por su parte, la playa de San Juan de Nieva se había pretendido promocionar con la construcción de un balneario en 1887, si bien fue desestimada por la proximidad a la dársena y malecones del nuevo puerto (Roza Candás, 1998, p. 190), de manera que la zona de baños quedó restringida al núcleo de Salinas.

Santander fue tras San Sebastián la gran estación balnearia del Cantábrico del siglo XIX y principios del XX. El Sardinero, a pocos kilómetros del centro urbano con sus playas acondicionadas para el baño desde que en 1868 se construyera el primer balneario, se fue colonizando con hoteles, palacetes y villas ajardinadas para alojamiento de los turistas, así como de infraestructuras de ocio necesarias para su tiempo libre como el casino, el hipódromo y el club de tenis. En el casco urbano de la ciudad también se habían acondicionado zonas de baño en las orillas de San Martín, la dársena de Molnedo y los muelles de Calderón que eran frecuentados por los propios santanderinos, especialmente por aquéllos con menor poder adquisitivo que no se podían costear el transporte y el pago del acceso a las playas de El Sardinero. Sin embargo, la actividad portuaria entre los muelles de Calderón y San Martín y la orientación cada vez más industrial de este último barrio fue ganando terreno a las prácticas balnearias. En San Martín se instalaron a lo largo del último cuarto de siglo, entre otros, los talleres metalúrgicos de López Dóriga, que rellenarían 
posteriormente la superficie de la playa, el gasómetro, el dique de Gamazo y una fábrica de azúcar. Sin embargo, los baños se mantuvieron hasta final de siglo, cuando el crecimiento portuario los expulsó definitivamente en favor de El Sardinero (Gil de Arriba, 1992, p. 78). Con ello culminaba el proceso de segregación espacial de usos en la Bahía de Santander, en el que la función recreativa vinculada a las playas se ubicaba en la periferia de la ciudad, mientras la función portuaria e industrial se localizaba en su fachada marítima de su centro urbano y en las rías de su arco Sur.

Astillero, ubicado en el interior de la bahía y que prestaba su nombre a una de esas rías, era sin duda uno de los ejemplos de población en la que la industria, en este caso con la importante ayuda de la minería del hierro, fue arrinconando a los turistas cuando no los expulsó hacia otros lugares libres de contaminación y aire más sano. En las siguientes páginas se analizará este proceso de consolidación industrial a costa de las actividades de ocio que se fue materializando a lo largo de la segunda mitad del siglo XIX, de manera que a comienzos del siglo XX era un núcleo plenamente industrial que casi había olvidado su pasado como centro de veraneo de la burguesía santanderina y castellana.

\section{Astillero como núcleo de ocio y turismo}

A mediados del siglo XIX el Astillero de Guarnizo, como todavía era conocido, era el punto de encuentro para el recreo y ocio de muchos comerciantes santanderinos que "allí tienen sus casas de campo, y allí van los domingos de verano a descansar de las fatigas del escritorio y de las elucubraciones del tanto por ciento, bajo la sombra de los cerezos y los perales" (El Americano, 19 de octubre de 1873). Asimismo, era el destino veraniego de muchos forasteros de ambas Castillas que también se alojaban durante el periodo estival en las numerosas quintas de estilo suizo que jalonaban el pueblo con deliciosas huertas, entre las que sobresalían las de los señores Aguirre y José María Botín (Madoz, 1984: pp. 52-53; Escalante, 1999). Tanto unos como otros se sentían atraídos por las salutíferas aguas ferro-carbonatadas de la fuente de La Planchada que combinaban con los baños de mar en su arenal.

Para facilitar la llegada de los veraneantes funcionaba en época estival un servicio de lanchas entre Santander y Astillero con tres viajes diarios (Boletín de Comercio de Santander, 14 de abril de 1849 y 1 de mayo de 1850), que en 1852 fueron sustituidos por vaporcitos que debían realizar el servicio durante todo el año (Boletín de Comercio de Santander, 9 de diciembre de 1852). Los visitantes procedentes de Madrid llegaban en diligencias por el Camino Real de Reinosa hasta que en 1866 se concluyera el Ferrocarril de Isabel II con estación en el vecino pueblo de Boo de Guarnizo, desde donde podían desplazarse a Astillero gracias a un servicio de alquiler de coches. 
Un hito en la historia de este Astillero veraniego se produjo con motivo de la visita de Isabel II el 4 de agosto de 1861. La Diputación Provincial ofreció a la Familia Real, que se encontraba en Santander desde el 20 de julio para tomar los baños de ola del Sardinero, la realización de un paseo por la bahía santanderina con descanso en el pueblo, que se había engalanado para la ocasión con un arco conmemorativo junto al muelle de desembarque y una calle adornada con guirnaldas de flores hasta una tienda de campaña donde se agasajó a los invitados con un buffet. Durante el paseo la reina visitó la fuente de la Planchada, si bien las crónicas de la época no informaron si probó sus aguas (Gaceta de Madrid, 8 de agosto de 1861).

Astillero se estaba reivindicando como un centro terapéutico y de ocio durante los años 50 y 60 del siglo XIX, aunque por supuesto sin llegar a competir con centros como San Sebastián o El Sardinero, a lo sumo complementando a estos. En el pueblo se reunían en los meses estivales conspicuas familias locales o madrileñas, como los Nacarino Bravo, los González Bravo o los Hermosa (La España, 7 de agosto de 1863), además de ilustres veraneantes como los ministros isabelinos Cándido Nocedal y el santanderino Pedro de Salaverría, que disponía de su propia quinta en el pueblo, probablemente por herencia familiar, a la que acudía puntualmente todos los veranos acompañado de su esposa e hijos, quienes, a su vez, mantendrían esta costumbre hasta ya entrado el siglo XX. La llegada de la familia Salaverría era todo un acontecimiento social en el pueblo, que obsequiaba al político con una velada con banda de música y fuegos artificiales, a la que también acudía "no poca gente de la ciudad" (La Época, 10 de julio de 1863; La Correspondencia de España, 6 de agosto de 1864). Para favorecer el progreso del veraneo residencial Venancio Tijero, alcalde de Astillero entre 1869 y 1879, facilitó la concesión gratuita de terrenos comunales a quienes quisiesen construir una casa de campo en Astillero y los permisos para la instalación de balnearios de baños de ola en la ría de Astillero (Arce Pinedo \& Miguel González, 2002, p. 18).

Los primeros veraneantes tenían una motivación fundamentalmente terapéutica. Según el médico local, las aguas de la fuente de La Planchada gozaban de justa fama, por cuanto habían "devuelto la salud a muchos seres desgraciados" por su conveniencia en el tratamiento de "todas las enfermedades sostenidas por debilidad y por trastornos nerviosos o perturbaciones funcionales a que ésta da lugar". Si bien era conveniente para un asegurado éxito su combinación con la toma de baños de la mar, lo que proporcionaba todos los años admirables curaciones, incluso en mujeres estériles (Adrau y Cornés, 1877, pp. 24-27).

No obstante, el disfrute de ambas terapias resultaba bastante complicado, por cuanto a comienzos de la década de los sesenta Astillero carecía de casas de baños adecuadas, de manera que las mujeres debían cruzar en bote hasta la orilla de Pontejos para bañarse "a cubierto de miradas imprudentes" (La Época, 11 de agosto de 1862). Al poco tiempo se construyeron unos baños flotantes que obtuvieron una merecida aceptación entre el público por su buen servicio y 
comodidad, más tarde fue ampliado y mejorado en vista del auge que el turismo terapéutico estaba adquiriendo (Boletín de Comercio, 6 de julio de 1872). Según explicaba el citado médico de la localidad, en 1877 junto al muelle de vapores se encontraba "un buen edificio avanzado a la playa con decentes habitaciones para recogerse, vestirse y desnudarse con toda comodidad, recato y pudor que el bello sexo tanto desea", con lo que se solventaban los problemas de la década anterior; la casa se completaba con un departamento para tomar baños templados, de chorro y de lluvia (Adrau y Cornés, 1877, pp. 17-18).

A partir de esta primera casa de baños la oferta fue ampliándose con nuevos establecimientos. En esas mismas fechas se concedió a Joaquín Bolado y Felipe Sánchez por Real Orden de 6 de junio de 1877 la construcción de una casa de baños y un embarcadero flotante para los que se reservaba un frente de 24 metros de playa (Gaceta de Madrid, 12 de junio de 1877). ${ }^{1}$ En 1883 Agapito Salas obtuvo la autorización, por Real Orden de 8 de abril, para la construcción de un varadero y una casa de baños compuesta de cuarenta cuartos (Gaceta de Madrid, 4 de mayo de 1883). ${ }^{2}$ La última en establecerse en Astillero fue construida ya en los años noventa por Victoriano Gorostegui, quien obtuvo la concesión por Real Orden de 14 de marzo de 1890 (Gaceta de Madrid, 25 de mayo de 1890), ${ }^{3}$ con un frente de 25 metros de longitud, que incluso permanecería abierta una vez que el turismo declinara.

Aparte de las quintas utilizadas como residencia de verano por parte de los santanderinos y algún madrileño, los veraneantes podían optar por el alquiler de casas en Astillero, que como tales se anunciaban en la prensa santanderina y madrileña, ${ }^{4}$ muchas de ellas en el nuevo barrio de Vista Alegre, que contaba con buenas habitaciones a la orilla del mar "perfectamente pintadas y amuebladas, destinadas a recibir huéspedes"; asimismo, el colegio naval, que se encontraba en ruinas, se acondicionó para transformarse en quince viviendas destinadas preferentemente a residencia secundaria (Adrau \& Cornés, 1877, pp. 18-19). A lo largo de la década de los setenta como complemento a esta oferta de alojamiento se construyeron algunos establecimientos hoteleros para veraneantes. En 1877 había dos fondas en el pueblo, la más importante era la denominada

1 AAPS, Expediente 6984/16 "Felipe Sánchez Díaz y Joaquín Bolado: construcción de una casa de baños y un embarcadero flotante en el Astillero de Guarnizo". Probablemente se trata del mismo edificio, ya que lo único que se pretendía era la legalización de unas obras y en los planos presentados no se aprecia la existencia de otra casa de baños en ese lugar.

2 AAPS, Expediente 1427/3 "Agapito Salas: proyecto para construcción de un varadero para la reparación y reforma de los buques y una casa de baños de mar en la playa del Astillero". No tenemos constancia de que se construyera, ya que en el expediente no se incluye la habitual acta de reconocimiento de las obras, si bien a partir de 1883 en los anuarios de Bailly-Balliere se anota una nueva casa de baños propiedad de Agustín Saurina, que bien pudiera ser la que se autorizaba.

3 AAPS, Expediente 4226/7 “Victoriano Gorostegui y Serna: establecimiento de un balneario en el pueblo de El Astillero, playa norte".

4 Véanse, por ejemplo, Boletín de Comercio, 8 de abril de 1868, 4 de junio de 1870 y 7 de abril de 1873; Diario Oficial de Avisos, 7 de julio de 1879; Los dominicales del libre pensamiento, 1 de junio de 1889; El Liberal, 28 de mayo de 1898. 
Fonda y Restaurant del Cid, de los señores Regatillo y Llaguno, ubicada junto a la Fuentuca y con acceso directo al muelle flotante y la casa de baños. Ambas estaban dotadas de habitaciones espaciosas, bien ventiladas y con abundante luz, amplios salones para el baile, azotea para tomar la brisa, mesas de billar, cafés, salones de recreo, piano... (Adrau y Cornés, 1877, p. 17). Antes de que concluyera la década se inauguraron al menos otras dos: la Fonda de los Vapores, de Manuel Goyechea, que también disponía de casino con gabinetes de lectura y recreo y un pequeño teatro, y la gran fonda de Francisca Puerta, ambas junto al muelle desembarcadero de las Corconeras. En la década siguiente la infraestructura hotelera se completó con El Cordón Bleu de Policarpo Maruri (Figura 2), el Hotel Dolores de Francisco Herrán, La Cantabria y la fonda de Juan Odelge.

\section{Figura 2. El Cordón Bleu y los Talleres de Bernardo Lavín en La Planchada a finales del siglo XIX}

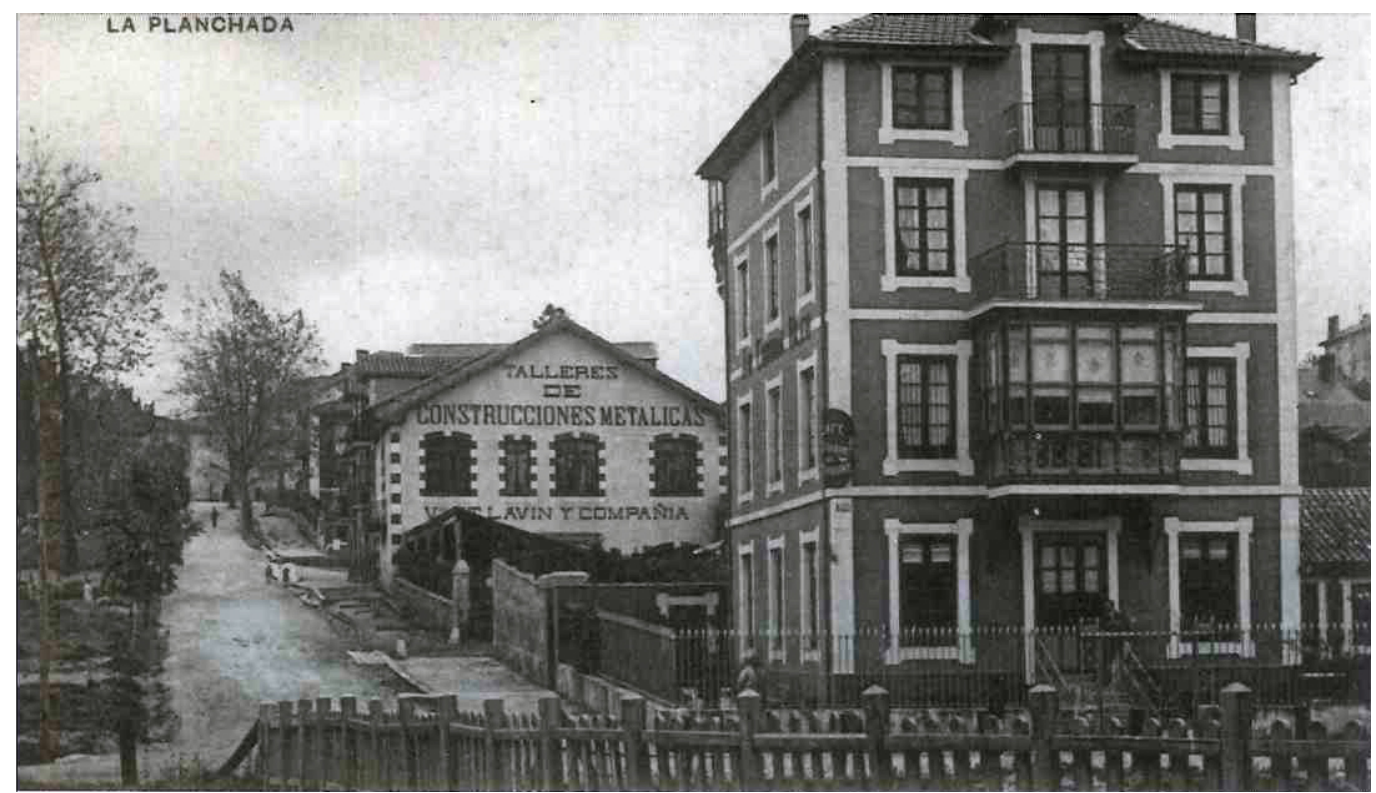

Fuente: Ayuntamiento de Astillero (n.d.)

Astillero se encontraba perfectamente adaptado a las necesidades de los veraneantes más allá de los baños, ya que se organizaban "muchas funciones, bailes campestres y espectáculos públicos que hacen cortos los días y evitan el aburrimiento" (El Imparcial, 12 de mayo de 1878). Estos alicientes también atraían a la gente de Santander, incluso a los foráneos que allí se encontraban de veraneo, por lo que no resultaba extraño encontrar en la prensa local anuncios sobre viajes de recreo desde la capital (Boletín de Comercio, 5 de junio de 1874 y 14 de agosto de 1875), que eran especialmente concurridos con motivo de la romería de Nuestra Señora (Boletín de Comercio, 16 de agosto de 1876). Incluso, el Marqués de Orovio, ministro de Fomento, realizó una excursión a Astillero cuando estuvo de veraneo en Santander (Boletín de Comercio, 2 de julio de 1875).

Los viajes de recreo se potenciaron desde 1877 cuando se puso en marcha el servicio de vapores entre Santander y Astillero conocidos como "corconeras". El impulsor de esta sociedad fue Juan Gutiérrez Colomer, asiduo veraneante en Astillero, junto a otros socios, como Felipe Sánchez Díaz 
y Joaquín Bolado Ibarra, promotores de una casa de baños en el propio muelle de la Corconera, el industrial Alberto Gutiérrez Vélez, el alcalde de Astillero Venancio Tijero y el habitual veraneante José María Aguirre (Gutiérrez Colomer, 1973, pp. 51-52). El 28 de junio comenzó el servicio con dos vaporcitos con capacidad para 97 y 130 pasajeros cada uno, que realizaban cinco viajes matutinos y seis vespertinos entre la capital y Astillero (Gutiérrez Colomer, 1973, p. 52). La flota se fue ampliando hasta contar con nueve vapores que también daban servicio a otros puntos de la Bahía de Santander como la playa de la Magdalena, el Puntal, Pedreña, Solía, San Salvador, además de realizar excursiones por la ría de Cubas. Para amenizar las jornadas dominicales en Astillero y, a su vez, conseguir un aumento de la clientela, la empresa organizaba un baile en La Planchada (Gutiérrez Colomer, 1973, p. 153). La apertura de la línea ferroviaria entre Solares y Santander en 1892 supuso una dura competencia para la compañía de vapores, que trató de contrarrestar con una política de precios económicos (Gutiérrez Colomer, 1973, p. 321). Sin embargo, no podía continuar con el servicio más allá de octubre, cuando "al llegar el frío acompañado de las lluvias, la mayoría de las gentes optan, como es lógico por el viaje en tren que es más confortable" (El Correo de Cantabria, 1 de octubre de 1895), hasta finalmente dejar de prestar servicio en 1899 (Gutiérrez Colomer, 1973, p. 492).

El auge del veraneo se prolongó hasta finales de siglo, sumándose nuevos ilustres visitantes, como la condesa de Brockmann, la familia de Joaquín López Dóriga, Antonia García del Mazo, el doctor Germán Asúa y el marqués de Albaida, que pasó sus últimos años de vida en Astillero una vez retirado de la vida política (Asúa y Campos, 1925, p. 109). Ya en el siglo XX también veranearon en la localidad la familia de Isidoro Millas, Fernando de la Sota, la señorita de Prendergast, los marqueses de Hinojeras o la marquesa de Santa Genoveva. Pero si duda quien más arraigo adquirió en la sociedad astillerense fue el maestro Tomás Bretón que desde al menos 1894 acudía regularmente todos los veranos a una quinta de su propiedad, en la que compuso la ópera La Dolores, motivo por el cual fue bautizada como hotel de La Dolores. Mercapide (1981) amplía la nómina de la selecta colonia con otros veraneantes como los condes de Plasencia, los periodistas Vildósola y Valentín Gómez, la familia de Marañón, Campos Guereta, Revilla, Sarabia, Hornedo y tantos otros.

\section{Astillero como núcleo industrial, minero y comercial}

Mientras Astillero se iba consolidando como una pequeña estación veraniega, desde el punto de vista industrial se asistía al final de una época y a la puesta de las bases de una nueva en el tránsito entre la protoindustria y la industria moderna. Por una parte, en 1871 se botaba la fragata Don Juan, el último barco salido de las gradas del viejo Astillero de Guarnizo que ponía punto final a casi tres siglos de construcción naval en la zona, si bien en sus últimos años apenas había tenido actividad, por lo que no menoscababa el disfrute de los veraneantes. Y, por otra parte, ya desde 
finales de la década anterior se veía merodear por Astillero al joven ingeniero de origen británico José Mac Lennan que se encontraba inspeccionando los montes próximos en busca de mineral de hierro y que seguramente se alojaría en alguna de las fondas para turistas construidas en esos años en Astillero.

No obstante, antes de que se produjera el despegue minero, que a su vez arrastraría al metalúrgico, un sector con nula tradición en España como el refinado de petróleo instalaría los primeros establecimientos industriales modernos en el municipio. Durante los años ochenta y noventa llegaron inversores e ingenieros extranjeros a Astillero para participar en dos negocios emergentes: el petróleo y las minas de hierro. Por tanto, no habría de resultar extraño que en los espacios de sociabilidad burguesa de Astillero, como los cafés y casinos, coincidieran los veraneantes con estos nuevos forasteros.

\subsection{El Astillero petrolero}

La primera generación de empresas especializadas en negocios de petróleo en España surgió en las dos últimas décadas del siglo XIX. Una de las primeras en establecerse en España fue la francesa Deutsch y Compañía que inauguró su factoría de Astillero en 1881, lo que sitúa a este municipio como uno de los pioneros en la actividad a nivel nacional junto a Palma de Mallorca, donde Manuel Salas inauguró su fábrica La Petrolera ese mismo año. ${ }^{5}$

La casa Deutsch y Compañía había nacido en 1879 como consecuencia de un acuerdo comercial entre los Rothschild, con crecientes intereses en los campos petrolíferos del Cáucaso, y el importador y refinador francés Deutsch de La Meurthe; en el accionariado también participarían posteriormente la Sociedad Minera y Metalúrgica Peñarroya y la Rio Tinto Company (López Morell \& O’Kean Alonso, 2008, p. 43). La casa francesa contaba en ese momento con tres fábricas de refinación en Francia (París, Rouen y Burdeos) y en España se instalaría también en Sevilla, Alicante y Badalona.

En junio de 1880 comenzó la construcción de la fábrica de Astillero, que se bautizaría como La Cantábrica, bajo la dirección del ingeniero Sr. Etienne, que se culminó en febrero de 1881 con el encendido de los hornos. En el momento de su inauguración la fábrica, dirigida por el Sr. Durney que provenía de otras fábricas de la compañía, constaba de diferentes edificios, con maquinaria muy avanzada en su tiempo, como las grandes bombas de absorción, los depósitos de hierro o las calderas, calculándose que las obras habían supuesto una inversión de cuatro millones de reales (Boletín de Comercio, 18 de febrero de 1881). Para facilitar la llegada de las materias primas se

5 Tortella et al. (2003, p. 45), en su listado de empresas especializadas en negocios de petróleo en España señalan la fábrica de la familia Salas como la más antigua de España. 
había construido un muelle de madera, autorizado por Real Orden de 3 de marzo de $1882 .^{6}$ En 1881 empleaba a unos 200 operarios, aunque paulatinamente su plantilla fue menguando, de manera que en la primera década del siglo siguiente apenas llegaba a unos cuarenta trabajadores. Se estimaba que la fábrica podría producir anualmente unas 400000 cajas de petróleo.

Los productos se comercializaban bajo la marca El León, denominación que compartía con el buque que realizaba el tráfico de petróleo. Entre estos sobresalían, de acuerdo con los anuncios publicitarios: Luz Brillante, un petróleo de calidad superior y refinado especial, ininflamable, que ardía en todas las lámparas para petróleo hasta la última gota sin olor y sin que disminuyera la intensidad de la llama; y la gasolina Motonafta, empleada en tractores, automóviles, motores, etc. Asimismo, producían aceites de semillas y abonos. Desconocemos el momento en que la fábrica dejó de refinar, si bien en 1923 tan sólo envasaba los productos que recibía por el muelle de madera. En esas fechas la empresa se había transformado en sociedad anónima, funcionando hasta su nacionalización como Sociedad Marca El León.

En marzo de 1891 comenzó la construcción de una segunda refinería contigua a la anterior, que fue inaugurada en el mes de agosto. La nueva fábrica era propiedad de la empresa francesa Desmarais Hermanos, que se había fundado en 1861 para la depuración y la distribución de aceites vegetales para el alumbrado y que progresivamente se orientó hacia el petróleo, utilizado también con este fin. En 1888 constituyó una filial española para la construcción de la fábrica de Astillero, que contaba con una avanzada instalación de refinación, compuesta por tres grandes calderas destinadas a destilar el petróleo, aparatos de fundición para destilaciones a elevada temperatura, dos generadores de vapor, una batería de 12 hornos y tres grandes depósitos de petróleo. Como Deutsch, disponía de un muelle en la ría, situado aguas debajo de aquél, que había sido autorizado por Real Orden de 5 de junio de 1891, ${ }^{7}$ para el atraque de buques de hasta 3000 toneladas, con un tubo de aspiración que conducía el petróleo directamente desde los barcos-tanque hasta los depósitos (Boletín de Comercio, 17 de julio de 1891). Las obras de construcción fueron dirigidas por M. J. Hugonnier, un ingeniero de la compañía desplazado desde Francia, mientras la dirección de la fábrica en los primeros años correspondió a León Alliot. Uno de sus productos más conocidos era la gasolina homogénea Automovilina para su uso en automóviles y toda clase de motores, lo que la hacía asidua a la feria de automóviles que anualmente se celebraba en Madrid. Pasado un tiempo adaptó este combustible para ser empleado también en aviación. 
Ambas empresas fueron nacionalizadas por la dictadura del General Primo de Rivera, que estableció un monopolio estatal sobre el comercio y manipulación del petróleo y constituyó la empresa estatal CAMPSA para la administración del negocio petrolífero en España. El Ministerio de Hacienda fijó una indemnización para la Sociedad Marca El León de algo más de 21 millones de pesetas por el conjunto de sus fábricas en España y de casi siete millones para Desmarais Hermanos, que desde 1918 era de capital español y cuya actividad productiva se centraba únicamente en Astillero, si bien disponía de almacenes en varias ciudades españolas.

De la mano de estas dos refinerías, Astillero cambió su fisonomía y podemos decir que fue el primer paso en la transformación que estaba viviendo el antiguo pueblo labriego y pescador, como indicaba Luis Redonet (Nuestro Tiempo, 1903, p. 512) "con sus chimeneas, sus edificios y sus tanques enormes, dan las fábricas al Astillero el aspecto industrial del Rhin, en la baja Alemania" (Figura 3). Probablemente este cambio no era tan visible socialmente, por cuanto en 1909 ambas fábricas tan sólo empleaban a 77 operarios, de los cuales ocho eran extranjeros que se ocupaban de la dirección y administración de las empresas.

Figura 3. Muelles y fábricas de petróleo a comienzos del siglo XX.

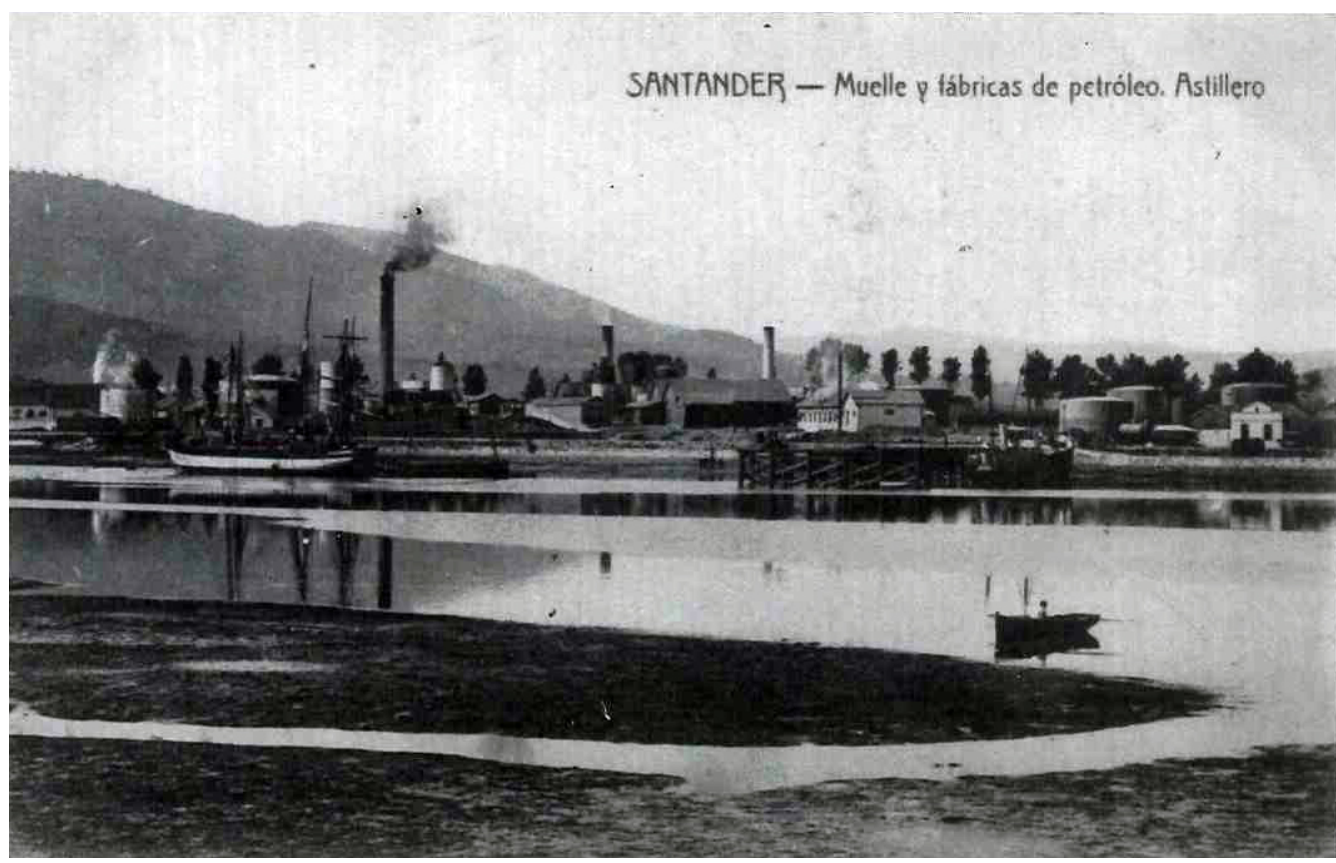

Fuente: Ayuntamiento de Astillero (n.d.)

Estas fábricas fueron sin duda un hito en la historia económica de Astillero, sin embargo, apenas se apreciaron en este tiempo cambios sustanciales en la vida del pueblo, que mantenía un comercio muy similar al de la década anterior, centrado en productos como las harinas, vinos, tejidos o carnes. Si bien se incorporaron algunas pequeñas manufacturas como dos fábricas de chocolate y tres constructores de carros, un sector cada vez más demandado, no sólo por las nuevas fábricas sino también por la minería. La instalación de las refinerías de petróleo configuró un nuevo espacio 
industrial al sureste del núcleo de Astillero, que se reforzó en los primeros años de la década de los noventa por cuanto será el lugar en el que se localice el cargadero de mineral de Mac Lennan.

\subsection{El Astillero minero}

En la década de los setenta comenzó la explotación de las minas de hierro de la cercana Sierra de Cabarga. Unos años antes comenzó a frecuentar Astillero el ingeniero británico José Mac Lennan, que se encontraba reconociendo los montes de la región en busca de mineral de hierro, tal como había hecho previamente en la vecina provincia de Vizcaya (González Urruela, 1995). La siderurgia británica desde la adopción del procedimiento Bessemer demandaba mineral con bajo contenido en fósforo, escaso en el subsuelo patrio, pero excepcionalmente abundante en Vizcaya y en menor medida también en la Bahía de Santander (Escudero, 1998). Fruto de sus pesquisas descubrió las minas más ricas de la comarca, la mayor parte de ellas situadas en los cercanos montes de Cabarga, que iría poniendo en explotación a lo largo de la década de los setenta. No obstante, esta novedosa actividad apenas repercutía en Astillero, por cuanto el mineral extraído se embarcaba en dos pequeños muelles que poseía en el fondo de la ría de Solía. Sus vecinos únicamente verían cruzar por su ría las gabarras cargadas de mineral que buscaban a los buques anclados en la bahía para trasegar el mineral a sus bodegas y seguramente también cómo sus aguas se teñían ocasionalmente del rojo mineral, pero todavía no era una actividad lesiva para el veraneo y el baño.

José Mac Lennan era consciente de la riqueza minera que ocultaban aquellos montes, pero para alcanzar el nivel de desarrollo deseado era necesario superar al menos dos rémoras: la dificultad para separar el mineral de la arcilla que lo envolvía y la ausencia de una infraestructura de transporte adecuada al volumen de mineral que se podía extraer. La primera se solucionó tras el envío de unas muestras de mineral a la casa alemana Humboldt, que aconsejó la utilización de trómeles deslodadores como el sistema más apropiado para la completa eliminación de las arcillas y, por tanto, para un mejor aprovechamiento del mineral. El problema del transporte era preocupante por cuanto lastraba todas las operaciones debido a su lentitud y provisionalidad al emplear carros para llevar el mineral desde las minas hasta los embarcaderos de la ría de Solía. A finales de la década de los ochenta emprendió un ambicioso plan, en el que proyectaba la construcción de un ferrocarril de vía estrecha desde las minas de Obregón hasta Solía, ${ }^{8}$ donde construiría un moderno lavadero, y su prolongación hasta la ría de Astillero, ${ }^{9}$ donde levantaría un

8 AGA, Sección Obras Públicas, legajo 28 239, "Proyecto de un ferrocarril de vía estrecha desde Obregón a los embarcaderos de la Ría de Solía". Fue autorizado por Real Orden de 26 de junio de 1889 para la ocupación del terreno público.

9 AGA, Sección Obras Públicas, legajo 27 528, "Proyecto de un ferrocarril de vía estrecha desde la Ría del Astillero a empalmar con el ferrocarril en construcción de Obregón al Puente de Solía en los depósitos de mineral del señor Mac Lennan". Fue autorizado para ocupar terreno público por Real Orden de 6 de noviembre de 1890. 
imponente cargadero, ${ }^{10}$ ya que los de Solía tenían poca capacidad, aparte de la obligación de realizar dobles cargas. La magnitud del proyecto determinó que las obras se prolongaran en el tiempo hasta que marzo de 1894 zarpó del nuevo cargadero el primer buque con sus bodegas repletas de mineral con destino a Middlesbrough (La Prosperidad, 8 de abril de 1894).

Mientras Mac Lennan estaba enfrascado en este proyecto, una compañía inglesa comenzó a lavar mineral en Liaño procedente de unas minas de Cabárceno que habían sido denunciadas en los años ochenta por los ingleses Juan Turner y Arturo Harrison. La compañía San Salvador Spanish Iron Ore se había fundado en Londres en 1889 promovida por el Martins Bank tras los informes positivo emitidos por dos ingenieros desplazados a Cantabria, Jeremías Head y Federico Kensington, que destacaban la elevada ley metálica del mineral, así como su extraordinaria abundancia. En realidad, la compañía funcionaba como una filial de la Consett Iron Ore a cuyos altos hornos enviaría toda su producción. Federico Kensington fue nombrado director facultativo de la compañía para lo que fijó su residencia en Astillero, tal como como harían otros ingenieros y contratistas de minas foráneos en aquellos años. El lavadero de Liaño y la cadena flotante que llegaba desde Cabárceno fueron inaugurados oficialmente en junio de 1890, lo que suponía la instalación de la primera gran compañía minera extranjera con la que se iniciaba una época de cambio y mutación de Astillero y sus núcleos más próximos (Cueto Alonso, 2006, pp. 41-42).

La siguiente compañía extranjera en interesarse por las minas de la comarca fue la Orconera Iron Ore, que desde 1873 explotaba con éxito un grupo de minas en Matamoros (Vizcaya). Sus socios fundadores fueron Dowlais Iron Ore de Dowlais (Gales), Consett Iron Ore de Durham (Inglaterra), que fueron sus promotores, la sociedad Krupp de Essen (Alemania) e Ybarra Hermanos y Cía., concesionarios de las minas de Vizcaya. No era una compañía explotadora de minas en sentido estricto, sino una asociación de empresas siderúrgicas que se abastecían de mineral, compartiendo los gastos de producción y asegurándose éste a un precio estable no fijado por el mercado (Cueto Alonso, 2006, pp. 42-43; Montero, 1988). Ante el aumento de la demanda de mineral por parte de las fábricas de sus socios la compañía entabló negociaciones con José Mac Lennan para lograr el arrendamiento de sus minas y la adquisición de todas sus instalaciones de Cabarga. Las conversaciones fructificaron en marzo de 1896 en París y fueron ratificadas notarialmente en noviembre en Santander. La noticia de este acuerdo fue acogida con entusiasmo por los santanderinos, dado que preveían que en corto espacio de tiempo pudiera aumentar el número de obreros empleados en las minas. De igual manera los vecinos de Astillero se mostraban esperanzados ante la nueva vida que podría tener la ría, un futuro en el que "Astillero sería el Liverpool de España" (El Correo de Cantabria, 21 de octubre de 1896). Aunque no se cumpliría

10 AGA, Sección Obras Públicas, Caja 700, Documento 4 (Signatura antigua). Plano del replanteo del cargadero de mineral de José Mac Lennan, fechado en 1891. Se autorizó la construcción del cargadero por Real orden de 17 de febrero de 1891. Un estudio detallado del cargadero puede consultarse en Cueto Alonso, 2004. 
este augurio, lo cierto es que durante casi cien años, hasta el cierre de las minas en 1989, Orconera se mantuvo en el primer puesto en la comarca en cuanto a producción y generación de empleo. El cargadero de Astillero aumentó notablemente su actividad durante los siguientes años; mientras en 1894 cuando se inauguró apenas se exportarían 30000 toneladas de mineral, tres años más tarde se superaban las 100000 y desde 1899 hasta el inicio de la I Guerra Mundial no bajaban de 200000 superando incluso las 300000 en 1907 (Cueto Alonso, 2006, pp. 372379).

La excelente marcha de los negocios mineros atrajo a nuevos inversores, en este caso mayoritariamente nacionales: en el último lustro de siglo fundamentalmente vizcaínos y a partir de 1900 santanderinos que buscaban nuevos negocios donde invertir. A raíz de la pérdida de las colonias ultramarinas en 1898, la burguesía santanderina, muy relacionada con el negocio portuario, decidió buscar nuevos derroteros en otros campos de actividad diferentes al comercio. Junto al capital acumulado gracias a los negocios coloniales, la ciudad disponía también de un importante volumen de capital repatriado en los años inmediatamente anteriores al desastre (Ortega, 1986). La minería, perfectamente consolidada como un negocio atractivo, fue unos de los sectores predilectos para la inversión, alentado por la posibilidad de obtener beneficios a corto plazo. Es la época conocida como la "fiebre de negocios" santanderina, que supuso la aparición en el entorno de Astillero de nuevas compañías como Minas Complemento, Minas de Solía y Minas de Liaño.

La inversión de capital en la minería del hierro consolidó definitivamente al sector como uno de los más pujantes de la provincia, lo que posibilitó un notable incremento de las cifras de producción que en algunos años de la primera década del siglo XX se acercaba al millón de toneladas que se exportaban no sólo por el cargadero de Orconera, sino también por otros dos nuevos construidos aguas arriba de Astillero en el fondeadero de San Salvador: el de la Compañía del Ferrocarril de Santander a Bilbao, inaugurado en 1896, que daba servicio a las minas de la zona oriental, y el de Minas Complemento, rehabilitado en 1902 para ampliar su capacidad de carga, por el que también exportaba la compañía de San Salvador. Como consecuencia del despegue minero el tráfico de buques por la ría de Astillero se intensificó notablemente. Se puede estimar, de acuerdo con los datos aparecidos en la sección marítima del Boletín de Comercio, que entre 1898 y 1904 partieron del Puerto de Santander 2295 buques, es decir, unos 300 anualmente, la mayor parte desde los tres cargaderos señalados, ya que las instalaciones portuarias de Santander tan sólo eran utilizadas por las compañías de Puente Arce y Camargo.

Desde luego este denso tráfico no habría de proporcionar la tranquilidad y sosiego que buscaban los veraneantes y sobre todo los turistas que acudían a Astillero. Sin embargo, este inconveniente no era el que más habría de perturbar a los bañistas, más perjudicial era la contaminación y suciedad de las aguas. El lavado del mineral en trómeles requería un gran volumen de agua, que 
por lo general no se encontraba en las proximidades de las minas, por lo que las compañías localizaron sus lavaderos en las márgenes de las rías que vertían sus aguas a la Bahía de Santander. Se calculaba que por cada metro cúbico de tierras eran necesarios al menos tres de agua para la perfecta separación del mineral de las arcillas. Es fácilmente comprensible que el volumen de fango generado en el proceso era enorme y antes del despegue minero era devuelto al cauce de las rías sin llevar a cabo su clarificación para eliminar las tierras en suspensión.

Los abusos que cometían las compañías mineras generaron una encendida polémica en la Bahía de Santander que se inició en 1897 y se prolongó durante la década siguiente. Pese a que en 1900 se promulgó un reglamento que obligaba a las compañías mineras a decantar los lodos resultantes del lavado con el fin de enviar las aguas limpias al cauce de las rías (Boletín Oficial de la Provincia de Santander, 5 de diciembre de 1900), éstas eludían habitualmente la normativa, ya que en una época de gran demanda de mineral les resultaba más rentable abonar las multas impuestas que realizar una correcta clarificación de los fangos en las marismas que tenían concedidas para tal fin. Las consecuencias de estas prácticas eran visibles en la Bahía de Santander, que reducía su calado, repercutía en actividades tradicionales como la pesca o el marisqueo, aparte de impedir que el ganado abrevara en las rías. Incluso desde la prensa santanderina se denunciaba los perjuicios que ocasionaba el enturbiamiento al veraneo del Sardinero (Cueto Alonso, 2006, p. 189).

Sorprende que en este clima de protestas generalizado no se alzara ninguna voz desde Astillero denunciando los abusos, por cuanto era uno de los municipios más afectados, aparte del trastorno que suponía para el disfrute de los bañistas. Este hecho evidenciaba que se había producido un cambio de modelo económico, ya no interesaba resaltar el pintoresquismo del pueblo como se había alabado en el pasado, sino las bonanzas que la minería y la industria reportaban. Los veraneantes, que continuaban acudiendo a Astillero, si bien en número más reducido, lamentaban el deplorable estado en que se encontraba la ría y sus márgenes cubiertos de fango, tal como denunciaba el músico Tomás Bretón al redactor de un periódico madrileño: "Nos han despojado, nos han destruido este Astillero, que era hace pocos años un rinconcito del Paraíso. Todos los días, invariablemente, vierten sobro la ría de 15000 a 20000 toneladas de polvo rojo, de fango, de basura. Y así se aniquila, desaparece, lo que formaba el encanto de los sentidos y del espíritu. El Astillero se va. El Astillero languidece, se hunde, se lo traga la mina, como si legiones de demonios volcaran aquí cuanto contiene el centro de la Tierra" (El Heraldo de Madrid, 2 de septiembre de 1903).

En definitiva, durante la última década del siglo XIX Astillero asumió su condición de capital minera de la Bahía de Santander. La demanda de mano de obra en las minas se había incrementado notablemente en un periodo de tiempo muy reducido y buena parte de los emigrantes que acudían 
en busca de trabajo se alojaban en las viviendas y albergues habilitados en su casco urbano, ya que en ese momento era el único pueblo preparado para acoger a ese voluminoso contingente de trabajadores. Asimismo, era el lugar de residencia de los ingenieros y personal facultativo foráneo que dirigían los trabajos en las minas. Astillero experimentó un exponencial crecimiento demográfico en el periodo del auge minero. Entre los censos de 1887 y 1897, casi duplicó su población; así, mientras en la primera fecha la población ascendía a 1572 habitantes, diez años más tarde era de 2880, multiplicándose por cuatro la población transeúnte, que pasó de 51 a 212, y que hemos de relacionar en parte con ese segmento de la población que iba asentándose para trabajar en las minas. En 1910 la población de Astillero alcanzaba su máximo con 5782 habitantes, duplicando a los existentes en el cambio de siglo.

\subsection{Diversificación industrial y comercial}

El comercio local tuvo que adaptarse para atender a la creciente demanda, que se manifestó en la diversificación de negocios comerciales y la aparición de nuevos oficios especializados, según se desprende de las guías y anuarios de la primera década del siglo XX. Los establecimientos de hostelería y ocio se fueron consolidando, si bien tan sólo se mantenía el establecimiento de baños de mar de Victoriano Gorostegui, que convivía con antiguos y nuevos hoteles, cafés con mesas de billar, el casino de Nemesio Tijero o el Salón Cortavitarte. A finales de la década (Dirección General..., 1911) estaban establecidas en Astillero tres carnicerías, nueve tiendas de comestibles, una confitería, dos farmacias, tres expendedurías de tabaco, tres barberías, dos cacharrerías..., así como algún nuevo comercio ligado a las actividades económicas dominantes del momento, como la tienda de efectos navales y artículos para minas de Álvarez Escalada y Compañía. Los artesanos habían aumentado (cuatro carpinteros, dos hojalateros y vidrieros, cuatro panaderos, dos pintores, dos relojeros, cuatro sastres, cinco zapateros) y aparecido otros nuevos (un maestro albañil, un grabador-litógrafo).

En el sector de la alimentación algunos pequeños establecimientos artesanales decidieron modernizar sus instalaciones incorporando avances como la introducción de motores de vapor y eléctricos en el proceso productivo para lograr un aumento de la producción, que no iba a destinarse únicamente a la población local. Tales fueron los casos de la fábrica de chocolates La Montañesa y la fábrica de pan y galletas La Providencia. Adolfo Jiménez había fundado La Montañesa en 1884; a su muerte se hicieron cargo del negocio sus hijos que operaron bajo la razón social Viuda de Ignacio Jiménez. En 1914 aparecía en la prensa nacional una reseña de esta fábrica: "es conocidísima en todo el Norte de España, y desde hace poco en toda la América latina, donde exporta grandes remesas de mercancías, especialmente a la República Argentina, en la que ha obtenido una extraordinaria acogida, debido a la bondad, a la pureza del chocolate que elabora, compuesto exclusivamente de cacao y azúcar puros, sin materias colorantes de ninguna 
clase" (ABC, 1914, July 10). Diariamente producía unas 500 libras, que también se despachaban en el Paseo Pereda de Santander donde también tenía su propio depósito, seguramente para facilitar su exportación. La Providencia de Casimiro Tijero producía diariamente dos toneladas de pan que se distribuía en Astillero y los pueblos circundantes, así como galletas que tenían gran aceptación entre el público local (ABC, 1914, July 10).

La evidente mutación que estaba sufriendo Astillero en la década de los noventa no pasó desapercibida para Bernardo Lavín, un joven forjador que había llegado en 1871 desde los talleres metalúrgicos de Domingo Corcho, a petición de Adrián Gassis, para colaborar en el remate de la fragata Don Juan. A la conclusión de la obra, Lavín, bien por consejo de éste, bien por iniciativa propia, decidió establecerse por su cuenta para lo que levantó su primer taller bajo una precaria tejavana (Mercapide Compains, 1977, p. 15). En 1877 se trasladó a un nuevo local y tras otros cambios de domicilio terminaría por asentarse al Oeste del parque de la Planchada. Estas sucesivas mudanzas no significaban que el negocio tuviera una gran dimensión, por cuanto en las guías y anuarios de los años setenta y ochenta se catalogaba a Lavín como herrero o cerrajero, lo que parece indicar que su mercado debía ser muy local. Seguramente no podía competir con sus producciones en la capital, ya que Santander estaba suficientemente dotada de talleres metalúrgicos, como los de Colongues, Corcho, Thomassin, Roviralta, Conce, López Dóriga... Tendría que esperar hasta la última década del siglo para alcanzar el éxito, gracias a su reorientación hacia dos sectores emergentes: el ferroviario y, sobre todo, el minero.

El prestigio de Bernardo Lavín se cimentó en la adaptación del sistema de lavado de mineral por medio de trómeles reduciendo su coste de instalación y por tanto haciéndolo más asequible a las compañías mineras. Este nuevo sistema denominado batidera, tuvo una excelente aceptación en la cuenca minera de la Bahía de Santander de la mano fundamentalmente de las empresas españolas, aunque también fue empleado por algunas foráneas (Cueto Alonso, 2006, p. 148). Dado el aumento de pedidos, los talleres de Lavín se fueron ampliando con nuevas naves que albergaban tornos mecánicos de distintos tamaños, máquinas de planchar, limar, cepillar, taladrar, muelas de esmerilar o incluso una sección de fundición. Aunque se construía y reparaba toda clase de maquinaria, como prensas, motores, turbinas, aparatos para molinos, calderas, ruedas dentadas... su especialidad era el material fijo y móvil para la industria minera como vagonetas, lavaderos mecánicos, dragas para el aprovechamiento de menudos, tolvas de decantación spitzkasten, elevadores de correas y de cangilones y la estrella de sus producciones: las batideras (Cueto Alonso, 2006, p. 109). Para el sector ferroviario fabricaba material móvil como vagones de gran capacidad, cisternas para el transporte de líquidos y plataformas, así como vías, cambios de vías, plataformas giratorias, cruces, semáforos, tomas y depósitos de agua. Durante la primera década del siglo XX la plantilla de los talleres superaba el centenar de operarios y en ocasiones se aproximaba a los doscientos. Por tanto, a la muerte del fundador en 1903 los primitivos talleres se 
habían convertido en un moderno establecimiento fabril que comenzó a funcionar bajo la razón social de Viuda de Lavín y Compañía como una sociedad en comandita de ámbito familiar.

Aunque social y económicamente Astillero estaba asistiendo a una profunda transformación podría haber sido más intensa si hubiera fructificado el proyecto para la instalación de una fábrica siderúrgica en su término municipal. El empresario José María Quijano decidió en los años finales del siglo liberarse de la dependencia de la palanquilla vizcaína que adquiría para sus forjas de Los Corrales de Buelna y construir sus propios altos hornos en la provincia para asegurarse el suministro a un precio asequible. Según sabemos, estuvo buscando terrenos apropiados en el ámbito de la Bahía de Santander y barajó la idoneidad de Astillero, si bien finalmente se ubicarían más próximos a la capital en la Isla del Óleo.

Esta pequeña decepción no menoscababa la imagen astillerense como un ámbito propicio para la inversión industrial. Sin embargo, no todas las iniciativas emprendidas en estos años se saldarían con éxito, como le sucedió al ingeniero José Villanova de Campos que en 1897 montó una fábrica metalúrgica en la finca Santa Ana, en Boo, en el límite con el municipio de Camargo (Boletín de Comercio, 19 de marzo de 1897; El Correo de Cantabria, 27 de octubre de 1897). Su especialidad era la producción de artículos de metal blanco, como candelabros, cafeteras, teteras, artículos de tocador y escritorio propios para servicios de fondas, cafés y casas particulares, que también se fabricaban en latón barnizado. Asimismo, fabricaba artículos de cocina corriente en acero y hierro Siemens laminado a frío y recocido, que se estampaba y después estañaba, método por el que su propietario tenía la patente en España. En menor medida, también se dedicaba a la fundición artística de objetos de adorno en plata, metal blanco, bronce, cobre y latón. El establecimiento se componía de varios pabellones que albergaban, entre otras secciones, los tornos mecánicos y de pulimentación, las máquinas para cortar las lanchas metálicas, las de cortes en redondo, los martillos pilones para la estampación, los baños eléctricos con sus pilas para el dorado, plateado o niquelado de las piezas, los hornos de fundición y el taller de bruñido y torneado. En definitiva, se trataba de un proyecto con grandes expectativas, como indicó su propietario en el acto de inauguración, que preveía a corto plazo su ampliación y la edificación de una pequeña barriada para sus obreros. No obstante, al poco tiempo la fábrica dejó de funcionar sin que conozcamos las razones de este precipitado final.

Paralelo al desarrollo industrial, se produjo también una mejora de las infraestructuras de transporte que habrían de facilitar el movimiento de mercancías y lógicamente también de personas. Como vimos, desde 1857 el municipio contaba con el moderno ferrocarril de Isabel II que, a partir de 1866 una vez concluida su construcción, facilitaba la llegada de veraneantes del interior (LópezCalderón Barreda, 2015). No obstante, su impacto sobre otras actividades económicas como la industrial o la minera fue mínimo por cuanto no atrajo nuevos establecimientos industriales y apenas repercutió en el transporte de mineral. En este sentido resultó más trascendente la inauguración en 
marzo de 1892 del ferrocarril de Santander a Solares que sí disponía de una estación en Astillero (Ajuria Ruiz, 2008, p. 23), que estaba concebido como uno de los tramos que unirían ferroviariamente Santander y Bilbao, que estaría concluido en julio de 1896. Aparte del transporte de viajeros, este nuevo ferrocarril facilitó también el de mineral de hierro de la zona oriental de la cuenca de la Bahía de Santander. En 1898 se concedió la construcción de un ferrocarril de vía estrecha entre Astillero y Ontaneda, que fue inaugurado en 1902, cuyo objeto era dar servicio a los visitantes de los balnearios de Puente Viesgo y Alceda y secundariamente el transporte de minerales de Cabarga, que habría de ser muy reducido. Aunque los viajeros podían desplazarse cómodamente por estos medios entre Astillero y Santander a partir de 1909 ambos núcleos también estuvieron conectados por medio de un tranvía (Gil de Arriba, 2016). Una cualidad sobresaliente de este nuevo transporte era su tracción eléctrica que aprovechaba el excedente energético que se generaba en la central eléctrica de los altos hornos de Nueva Montaña, lo que no extraña por cuanto el promotor de este medio de transporte fue la propia siderurgia (Ajuria Ruiz, 2008, p. 61).

Con los nuevos establecimientos industriales y la diversificación sectorial, junto a estos medios de transporte, Astillero estaba mutándose en un pueblo fabril que olvidaba su pasado veraniego y turístico. Seguramente el año de 1913 fue el punto de inflexión definitivo del proceso. Industrialmente se pusieron las bases de una cierta diversificación sectorial y la incorporación de nuevas actividades. Por una parte, se constituía Talleres de Astillero S.A., heredera de los viejos talleres de Bernardo Lavín, que hábilmente orientará su negocio hacia la actividad naval una vez que la minería empezaba a mostrar su decadencia; y, por otra parte, se inauguraba la fábrica de la Electro Metalúrgica de Astillero dedicada a la producción de carburo de calcio. De la propia denominación de esta última se puede inferir que se estaba produciendo también un cambio energético en la industria local gracias a la central que Electra de Viesgo había montado en el municipio para abastecer a las fábricas y minas de la Bahía de Santander.

Por tanto, en primer lugar, parece oportuno referirse al cambio energético. Electra de Viesgo se constituyó en julio de 1906 (Madrazo Feliú, 1981), si bien su origen se remontaba al año anterior cuando Calixto Rodríguez, uno de sus futuros fundadores, compraba los bienes y derechos de la Sociedad General de Centrales Eléctricas. La nueva compañía tan sólo contaba en ese momento con una central hidroeléctrica en Puente Viesgo, una línea eléctrica trifásica entre Puente Viesgo y Santander y una central en la ciudad. Sin embargo, en breve se produjeron algunos cambios significativos: sus acciones fueron adquiridas por el Banco de Vizcaya y Lucas Urquijo y al poco absorbió a la Hidroeléctrica Ibérica. Esta última había comenzado en 1910 la construcción de una central térmica y una subestación eléctrica en Astillero con una línea de alta tensión desde el salto de Urdón en el valle del río Deva; esta infraestructura era la respuesta al cambio energético que se estaba produciendo en la industria minera de la Bahía de Santander con una progresiva sustitución 
de los motores de vapor por los eléctricos, que Electra de Viesgo aceleraría. Como parece lógico esta novedosa energía también fue aprovechada por las fábricas de la Bahía de Santander.

Una de éstas fue la Electro-Metalúrgica de Astillero, que se fundó en 1913 para la fabricación de carburo de calcio (Fernández Vega \& Sánchez Landeras, 2013). En el momento de su construcción se componía de tres hornos eléctricos alimentados por otros tantos transformadores, aparte de los servicios auxiliares necesarios como hornos de cal, aparatos de trituración, elevación y transporte de las primeras materias y un equipo completo para la clasificación y embalaje del producto final. Un inicio modesto para una empresa que un siglo más tarde continúa en actividad, actualmente bajo la denominación de Ferroatlántica.

En 1913 también se constituyó la sociedad anónima Talleres del Astillero, Herederos de Bernardo Lavín (Mercapide Compains, 1977, p. 47). Aunque en principio continuó su dedicación al negocio que tanto éxito le había proporcionado en años precedentes, es decir, la construcción y reparación de todo tipo de maquinaria, lavaderos de mineral, cerrajería, trabajos para minas y ferrocarriles, etc., el encargado Alfredo Chelvi entendió que era un momento oportuno para abrir una nueva línea de negocio con la reparación de buques, habida cuenta de los numerosos barcos que llegaban a la ría para cargar mineral. Lógicamente para esta nueva orientación era preciso que la empresa se dotase de nuevos terrenos junto a la ría para lo que adquirió en 1918 una marisma a Leopoldo Cortines en la que construyó un dique seco. La nueva línea de trabajo se debe considerar como muy acertada, por cuanto se apreciaba una pérdida de pujanza de la minería que se acentuaría muy poco tiempo después.

El estallido de la guerra en Europa a comienzos de agosto de 1914 alteró la marcha de la minería del hierro, no sólo en Cantabria sino en todo el país, que, en declive desde mediados de 1913, no pudo soportar el revés causado por la guerra, comenzando a declinar en una lenta pero larga etapa de la que no se recuperaría. El conflicto entre los dos principales consumidores del mineral santanderino, Gran Bretaña y Alemania paralizó prácticamente las exportaciones ante la peligrosidad que entrañaba el transporte hasta los puertos del norte de Europa. Así, las compañías de menor relevancia debieron cerrar definitivamente sus instalaciones a causa de la baja de los precios que no permitía la entrada en el mercado de sus minerales, debido a su inferior calidad y alto coste de producción, mientras las más grandes sobrevivieron a duras penas a esta adversa situación (Cueto Alonso, 2006, pp. 68-72).

\section{Conclusiones}

Astillero en los últimos años del siglo XIX y los primeros del XX sufrió una profunda transformación territorial, económica y social que fue vivida con grandes esperanzas por la población local, aunque desde luego no llegaría a ser "el Richmond de los comerciantes santanderinos", como refería un 
periodista, en la época del auge veraniego, ni se asemejó a la cuenca del Rhin o Liverpool, como señalaron otros, cuando se instalaron los establecimientos industriales, almacenes y cargaderos y diariamente su ría era transitada por vapores que cargaban mineral con destino a los altos hornos europeos.

A mediados del siglo XIX, como otras muchas localidades próximas a centros urbanos con un cierto desarrollo económico, era un lugar de veraneo consolidado que también atraía a población foránea. En esos momentos el carácter protoindustrial del Real Astillero de Guarnizo apenas entorpecía la calma y sosiego que buscaban los veraneantes. Sin embargo, la irrupción de nuevas actividades más contaminantes en las siguientes décadas, como la industria petrolera, la metalúrgica y sobre todo la actividad minera, fueron desplazando a Astillero como destino veraniego, de manera que en el siglo XX el turismo ya podía considerarse como una actividad residual.

Como resultado de esta nueva orientación económica Astillero se transformó paisajísticamente y en la segunda década del siglo XX su fisonomía apenas recordaba su pasado turístico, con las aguas de su ría teñidas de mineral, con chimeneas como hitos singulares de su skyline, con los viejos lugares de baño ocupados por diques y almacenes o con cargaderos en los bordes de la ría. El carácter minoritario del turismo, que todavía no se veía como una oportunidad de negocio, no pudo competir territorialmente con las actividades industriales, portuarias y mineras, como sucedía en ese tiempo en otros muchos lugares de la costa cantábrica. El municipio contaba con más de 5000 habitantes y necesitaba un comercio acorde a sus necesidades, de manera que se fue paulatinamente diversificando. Asimismo, iban surgiendo nuevas profesiones también especializadas para atender a la demanda de la nueva población. Este cambio en su economía tuvo su lógico reflejo en la sociedad. La industria se convirtió en el destino laboral de buena parte de la población que en el pasado vivía del sector primario tanto en Astillero y pueblos más próximos y también para los que se desplazaron hasta aquí en busca de trabajo desde otras provincias. Esta proletarización de la población supuso que Astillero se convirtiera durante los primeros años del siglo XX en el foco de irradiación del socialismo fuera de Santander. En definitiva, como recordaba Miguel de Asúa en 1923 "cambió de la vida tranquila, silenciosa, de descanso, que se disfrutaba antes, por otra accidentada, ruidosa, de actividad y de inquietud"

Declaración responsable: El autor declara que no existe ningún conflicto de interés en relación a la publicación de este artículo. 


\section{Bibliografía}

ABC (1914, July 10).

Adrau y Cornés, J. (1877). Memoria acerca de las aguas ferro-carbonatadas del Astillero, topografía de este pueblo y descripción de los establecimientos que se han construido para tomar baños de mar. Santander: Impr. de Telesforo Martínez.

Aguirre y Escalante, J. M. (1910). La vena del hierro. Madrid: Los Contemporáneos.

Ajuria Ruiz, J. (Coord.) (2008). Patrimonio ferroviario de Cantabria. Inventario del material ferroviario que prestó servicio en la Comunidad Autónoma de Cantabria. Santander: Consejería de Medio Ambiente del Gobierno de Cantabria.

Arce Pinedo, R., \& Miguel González, R. (2002). Cultura, sociedad y política en Astillero-Guarnizo (1890-1910). Microhistoria de una sociedad en cambio. Astillero: Ayuntamiento de Astillero.

Archivo de la Autoridad Portuaria de Santander (AAPS) (1876, November 23). Expediente 6984/16. Felipe Sánchez Díaz y Joaquín Bolado: construcción de una casa de baños y un embarcadero flotante en el Astillero de Guarnizo.

Archivo de la Autoridad Portuaria de Santander (AAPS) (1883). Expediente 1427/3. Agapito Salas: proyecto para construcción de un varadero para la reparación y reforma de los buques y una casa de baños de mar en la playa del Astillero.

Archivo de la Autoridad Portuaria de Santander (AAPS) (1890). Expediente 4226/7. Victoriano Gorostegui y Serna: establecimiento de un balneario en el pueblo de El Astillero, playa norte.

Archivo de la Autoridad Portuaria de Santander (AAPS) (1880, July 23). Expediente 4219/2. Deutsch y Cía (París). Construcción de un muelle saliente (o wharf) en la zona marítimo-terrestre de la canal del Astillero, la Puntona.

Archivo de la Autoridad Portuaria de Santander (AAPS) (1890, January 10). Expediente 4222/2. Sociedad Desmarais Hermanos. Muelle embarcadero para servicio de una fábrica de petróleo en la margen izquierda de la ría de Astillero.

Archivo General de la Administración (AGA) (1887, June 21). Sección Obras Públicas, legajo 28 239, Proyecto de un ferrocarril de vía estrecha desde Obregón a los embarcaderos de la Ría de Solía.

Archivo General de la Administración (AGA) (1889, May 24). Sección Obras Públicas, legajo 27 528, Proyecto de un ferrocarril de vía estrecha desde la Ría del Astillero a empalmar con el ferrocarril en construcción de Obregón al Puente de Solía en los depósitos de mineral del señor Mac Lennan. 
Archivo General de la Administración (AGA) (1891). Sección Obras Públicas, Caja 700, Documento 4, (Signatura antigua). Plano del replanteo del cargadero de mineral de José Mac Lennan.

Asúa y Campos, M. de (1925). El Real Astillero de Guarnizo. Apuntes para su historia y la de los pueblos de Guarnizo y Astillero. Madrid: Imp. Aldecoa.

Ayuntamiento de Astillero (s.f.). Astillero al despertar el siglo. Astillero: Ayuntamiento de Astillero.

Barral Martínez, M. (2012). Casas de baños y balnearios en el desarrollo del turismo en Galicia: el caso de Vigo y Mondariz. Paper presented at the XI Congreso de Historia Contemporánea. Granada, September 12-15.

Beascoechea Gangoiti, J. M. (2002). Veraneo y urbanización en la costa cantábrica durante el siglo XIX: las playas del Abra de Bilbao. Historia Contemporánea, 25, 181-202.

Boletín de Comercio (1872-1904). 1868, April 8; 1870, June 4; 1872, July 6; 1873, April 7; 1874, June 5; 1875, July 2; 1875, August 14; 1876, August 16; 1881, February 18; 1891, July 17; 1897, March 19.

Boletín de Comercio de Santander (1849, April 14; 1850, May 1; 1852, December 9).

Boletín Oficial de la Provincia de Santander (1900, December 5).

Cava Mesa, M. J. (2009). Balnearios y baños de ola en Bizkaia. Itsas Memoria, Revista de Estudios Marítimos del País Vasco, 6, 369-380.

Cueto Alonso, G. J. (2004). El cargadero de Orconera en la Ría de Astillero: un elemento singular del patrimonio minero de Cantabria. En Rutas culturales y turísticas del patrimonio industrial (pp. 167-176). Gijón: INCUNA, Asociación de Arqueología Industrial.

Cueto Alonso, G. J. (2006). La minería del hierro en la Bahía de Santander, 1841-1936. Un estudio de Geografía Histórica. Santander: Consejería de Medio Ambiente de Cantabria, Centro de Investigación del Medio Ambiente.

De la Madrid, J. C. (2011). Aquellos maravillosos baños. Historia del turismo en Asturias, 18401940. Gijón: Fundación Caja Rural de Asturias.

Diario Oficial de Avisos (1879, July 7).

Dirección General De Comercio, Industria y Trabajo (1911). Estadística Comercial e Industrial de la Provincia de Santander correspondiente al año 1909. Madrid: Impr. Artes Gráficas.

El Americano (1873, October 19).

El Correo de Cantabria (1895, October, 1; 1896, October, 21; 1897, October 27).

El Heraldo de Madrid (1903, September 2). 
El Imparcial (1878, May 12).

El Liberal (1898, May 28).

Escalante, A. de (1999) [1871]. Costas y Montañas. Santander: Estvdio.

Escudero, A. (1998). Minería e industrialización de Vizcaya. Barcelona: Crítica, Universidad de Alicante.

Fernández Vega J. L., \& Sánchez Landeras, J. L. (2013). Ferroatlántica. Un siglo de Industria Española y Cántabra. Santander: Ferroatlántica S.A.

Fernández-D’Arlas de la Peña, A. (2009). Una incursión en el patrimonio marítimo donostiarra. Las casetas de baño, germen de la arquitectura balnearia. Itsas Memoria, Revista de Estudios Marítimos del País Vasco, 6, 343-368.

Gaceta de Madrid (1861, August 8; 1877, June 12; 1883, May 4; 1890, May 25).

Gil de Arriba, C. (1990). La génesis de las actividades de ocio en Cantabria. Estudio del caso de Comillas. Treballs de Geografía, 43, 111-118.

Gil de Arriba, C. (1992). Casas de baños de ola y balnearios marítimos en el litoral montañés, 1868-1936. Santander: Universidad de Cantabria, Fundación Marcelino Botín.

Gil de Arriba, C. (1994). La práctica social de los baños de mar. Establecimientos balnearios y actividades de ocio en Cantabria (1868-1936). Documents d'Anàlisis Geogràfica, 25, 79-97.

Gil de Arriba, C. (2000). La difusión social y espacial del modelo balneario: de la innovación médica al desarrollo de las prácticas de ocio. Scripta Nova, 69(40). Retrieved from http://www.ub.edu/geocrit/sn-69-40.htm

Gil de Arriba, C. (2016). Tranvías en Santander. Los inicios del transporte urbano, 1846-1923. TST: Transportes, Servicios y telecomunicaciones, 31, 88-119.

Gonzalez Urruela, E. (1995). José Mac Lennan, un empresario montañés. Cámara Cantabria, 33, 32-37.

Gutiérrez Colomer, R. (1973). Santander 1875-1899. Santander: Institución Cultural de Cantabria, Centro de Estudios Montañeses, Diputación Provincial de Santander.

La Correspondencia de España (1864, August 6).

La Época (1862, August 11; 1863, July 10).

La España (1863, August 7).

La Prosperidad (1894, April 8). 
Larrinaga Rodríguez, C. (2002). El turismo en la España del siglo XIX. Historia Contemporánea, 25, 157-179.

Larrinaga, C. (2005). La madurez de un producto turístico: el País Vasco entre 1876 y 1936. Paper presented at the VIII Congreso Internacional de la Asociación Española de Historia Económica, Santiago de Compostela, Spain, September 13-16.

Larrinaga, C. (2015). De las playas frías a las playas templadas: la popularización del turismo de ola en España en el siglo XX. Cuadernos de Historia Contemporánea, 37, 67-87. doi: http://dx.doi.org/10.5209/rev_CHCO.2015.v37.50987

Larrinaga, C., \&Pastoriza, E. (2010). Dos balnearios atlánticos entre el fin de siglo y la crisis del treinta, San Sebastián y Mar del Plata. Un ejercicio comparativo. Historia Contemporánea, 38, 277-310.

López Morell, M. Á., \& O’Kean Alonso, J. M. (2008). La red de negocios de la Casa Rothschild en España como una estructura de toma de decisiones y de gestión empresarial. Revista de la historia de la economía y de la empresa, 2, 41-64.

López-Calderón Barreda, M. (2015). El camino de hierro de Alar del Rey a Santander. Del ferrocarril de Isabel I/ al final del monopolio de Renfe. Santander: Asociación Cántabra de Amigos del Ferrocarril.

Los dominicales del libre pensamiento (1889, June 1).

Macías, O. (2009). La perla del Nervión en el siglo XIX: Portugalete. Revista AVNIA, 27, 3-20.

Madoz, P. (1984). Diccionario geográfico, estadístico e histórico. Santander: Facsimilar. Valladolid: Ámbito, Libr. Estvdio.

Madrazo Feliú, B. (1981). Electra de Viesgo. 75 años. Santander: Impr. Cervantina.

Mercapide Compains, N. (1977). Crónica de Astilleros de Santander S. A. Años 1872-1877. Santander.

Mercapide, N. (1981). Guarnizo y su Real Astillero. Santander: Institución Cultural de Cantabria, Diputación Provincial.

Montero, M. (1988). The Orconera Iron Ore Co. Ltd. en la explotación del hierro de Vizcaya en el siglo XIX: bases mineras, contractuales y organizativas. En 25 años. Facultad de Filosofía y Letras. II. Estudios de Geografía e Historia (pp. 595-610). Bilbao: Universidad de Deusto.

Ortega Valcárcel, J. (1986). Cantabria 1886-1986. Formación y desarrollo de una economía moderna. Santander: Estvdio, Cámara de Comercio, Industria y Navegación de Santander.

Redonet, L. (1903). La industria en Santander. Nuestro Tiempo, 28, 503-514. 
Redonet, L. (1903, April 28). La industria en Santander. Nuestro Tiempo, 28, 503-514.

Roza Candás, M. (1995). Los balnearios marítimos en Asturias (1848-1935). Gijón: Fundación Alvargonzález.

Sazatornil Ruiz, L. (2007). Los orígenes del veraneo en España: playas urbanas, ciudades balneario y arquitectura elegante. En J. L. Estrada Llaquet et al. (Eds.), Playas urbanas. IV Curso Internacional de Relaciones Puerto-Ciudad (pp. 49-73). Santander, Autoridad Portuaria de Santander Sazatornil Ruiz, L. (2009). Arquitectura, salud y ocio: la edad de oro de los balnearios. En J. M. Iglesias Gil (Ed.), Actas de los XIX Cursos Monográficos sobre el Patrimonio Histórico (pp. 133153). Reinosa, July 2008. Santander: Ediciones de la Universidad de Cantabria.

Suárez Antuña, F. (2006). Carbón para España: la organización de los espacios hulleros asturianos. Gijón: KRK Ediciones.

Tatjer, M. (2009). En los orígenes del turismo litoral: los baños de mar y los balnearios marítimos en Cataluña. Scripta Nova, 296(5). Retrieved from http://www.ub.edu/geocrit/sn/sn-296/sn296-5.htm

Tortella, G., Ballestero, A., \& Díaz Fernández, J. L. (2003). Del Monopolio al libre mercado. La historia de la industria petrolera en España. Madrid: LID Editorial Empresarial.

Valero, A. (1994). El turismo de playa en España entre 1850 y 1950. Creación, madurez y crisis. En F. Fourneau, \& A. M. García Lorca (Coords.), Desarrollo regional y crisis del turismo en Andalucía: Actas del simposio hispano-francés (pp. 297-329). Almería, June 25-29, 1991. Almería: Instituto de Estudios Almerienses.

Zurbano Melero, J. G. (2003). El comercio por los puertos de Pasajes y San Sebastián durante el siglo XX. Itsas Memoria, Revista de Estudios Marítimos del País Vasco, 4, 421-444. 